\title{
New Complexes with Triazole Schiff Bases Derivative Ligand Containing Aspirin: Synthesis, Structure, Conductivity and Magnetic Susceptibility
}

\author{
Ahlam S. Dakhil*, Zaki N. Kadhim and Zeki A. Naser Al-Shamkhani \\ Department of Chemistry, College of Science, University of Basrah \\ Basrah, Iraq \\ *Corresponding author's email: bgc1722008 [AT] gmail.com
}

\begin{abstract}
Complexes of $\mathrm{Cu}(\mathrm{II})$ ), Ni (II) and Co (II) of a new triazole Schiff-base of two different ligand ,namely(E)-2-(4-((2-hydroxybenzylidene)amino)4H- 1,2,4-triazol-3-yl)phenyl acetate and (E)-2-(4-((2-hydroxy-4methoxybenzylidene)amino)-4H-1,2,4-triazol-3-yl)phenyl acetate were prepared and characterized by elemental analysis, ${ }^{1} \mathrm{H},{ }^{13} \mathrm{C}$-NMR, FTIR and $\mathrm{UV}$-Visible spectroscopic data. The complex is found to be an ionic in nature by conductivity measurements and have been found to posses 1:2(M:2L) stoichiometry. The magnetic moment values of 1.540-1.7295.B.M. for Cu(II) complexes without doubt recommend octahedral geometry with one unpaired electron for $\mathrm{Cu}(\mathrm{II})$ complexes. The magnetic moment values of 3.863-4.039 B.M. for Co(II) complexes that recommend high spin octahedral geometry with three unpaired electron for Co(II) complexes. The magnetic moment value of 2.351B.M. for $\mathrm{Ni}(\mathrm{II})$ complex was matches to two unpaired electrons and octahedral geometry. Considerable variations in biological activity with structure and types are observed for these complexes.
\end{abstract}

Keywords--- Aspirin, Electrochemistry, Magnetic susceptibility, Triazole, Complexes

\section{INTRODUCTION}

Metal complexes of Schiff base have played a central role in the development of coordination chemistry [1]. Various Schiff base complexes have been widely studied because they have antimicrobial, anticancer, analgesic, anti-inflammatory, antfertility, and herbicidal applications [2,3]. Chelating ligands containing $\mathrm{N}, \mathrm{N}$, and $\mathrm{O}$ donor atoms show broad biological activity and are of special interest because of the ways in which they are bonded to the metal ions [4]. It is known that existence of metal ions bonded to biologically active compounds may enhance their activities [5-7]. Even though many Schiff bases using salicylaldehyde and substituted salicylaldehyde and amines had been studied [8-11] as ligands, no work had been done with salicylaldehyde and aminotriazole as the basic nucleus of Schiff bases. Schiff base metal complexes had been a widely studied subject to their industrial and biological applications [12].The synthesis, physicochemical characterization, and biological activity of 2-aminobenzimidazole complexes with different metal ions have been reported [13]. An efficient synthesis of Schiff bases containing triazole moiety catalyzed by transition metal nitrates had been done [14]. The synthesis and antimicrobial activity of $\mathrm{Cu}$ (II), Co (II), and Ni (II) complexes with 2-aminotraizole were available [15]. The present work amid to synthesis and characterization of three Schiff base complexes derived from trizole of aspirin with salicylaldehyde and o-vanillin.

\section{EXPERIMANTAL}

Melting point apparatus and were uncorrected, Elemental analysis(CHN) were recorded in EA300 Euro-Vector in University of Tehran-Iran. FT-IR Spectra were recorded on Shimadzu FT-IR 8400 Fourier Transformer infrared as KBr disk. Ultraviolet spectra were recorded in spectro scan 80 inthe wave length $200-800 \mathrm{~nm} .{ }^{1} \mathrm{HNMR}$ and ${ }^{13} \mathrm{CNMR}$ spectrawere recorded on Bruker spctrospin ultra shield magnets $400 \mathrm{MHz}$ instrument using tetramethyl silane (TMS) as an internal standard and DMSO-d6 as a solvent in university of Tabriz-Iran. Thin layer chromatography were performed on pre-coated sheets with $0.25 \mathrm{~mm}$ layer of Slica Gel GF254 of the Merck Company.

Synthesis of Compounds:

\section{1- Synthesis of Triazole}

Synthesis of Triazole equimolar amounts of thiocarbohydrazide and appropriate carboxylic acids ( $10 \mathrm{mmol}$ of each ) were mixed and heated at $180{ }^{\circ} \mathrm{C}$ for $45 \mathrm{~min}$. Boiling water $(20 \mathrm{ml})$ was add to the solid and the mixture was kept at room temperature for $24 \mathrm{~h}$. The precipitate was filtered and recrystallized from ethanol . 
2- Synthesis of Schiff Base.

The Schiff base was prepared by mixing equimolar amounts $(0.001 \mathrm{~mole})$ of amino triazole and the aromatic aldehyde in ethanol. The mixture was refluxed for about 4 hours. Concentration of the solution was done to reduce it to one-half of its original volume when deep yellow crystals were formed in the reaction mixture, which were filtered, washed thoroughly with the same solvent, and recrystallized with acetone. The yellow Schiff base product obtained (m.p. $138 \& 125^{\circ} \mathrm{C}$ ) produced in $65 \& 75 \%$ respectively yield was subjected to analysis $[16,17]$.

3- $\quad$ Synthesis of complexes

0.02Mole solution of SB and 0.02Mole metal salt solution were prepared separately in pure ethanol and mixed. Colour of the resulting solution was yellow green. The $\mathrm{pH}$ of the solution was raised to 7.5 by adding $10 \mathrm{~N} \mathrm{NaOH}$ solution. This solution was refluxed for 4 hours and kept for four days when pale green colored product was obtained. This product was then filtered, washed with the same solvent, dried over fused $\mathrm{CaCl}_{2}$, weighed, and subjected to analysis [18].

\section{RESULTS AND DISCUSSION}

In the present work new complexes, compounds were synthesized as shown in scheme below:

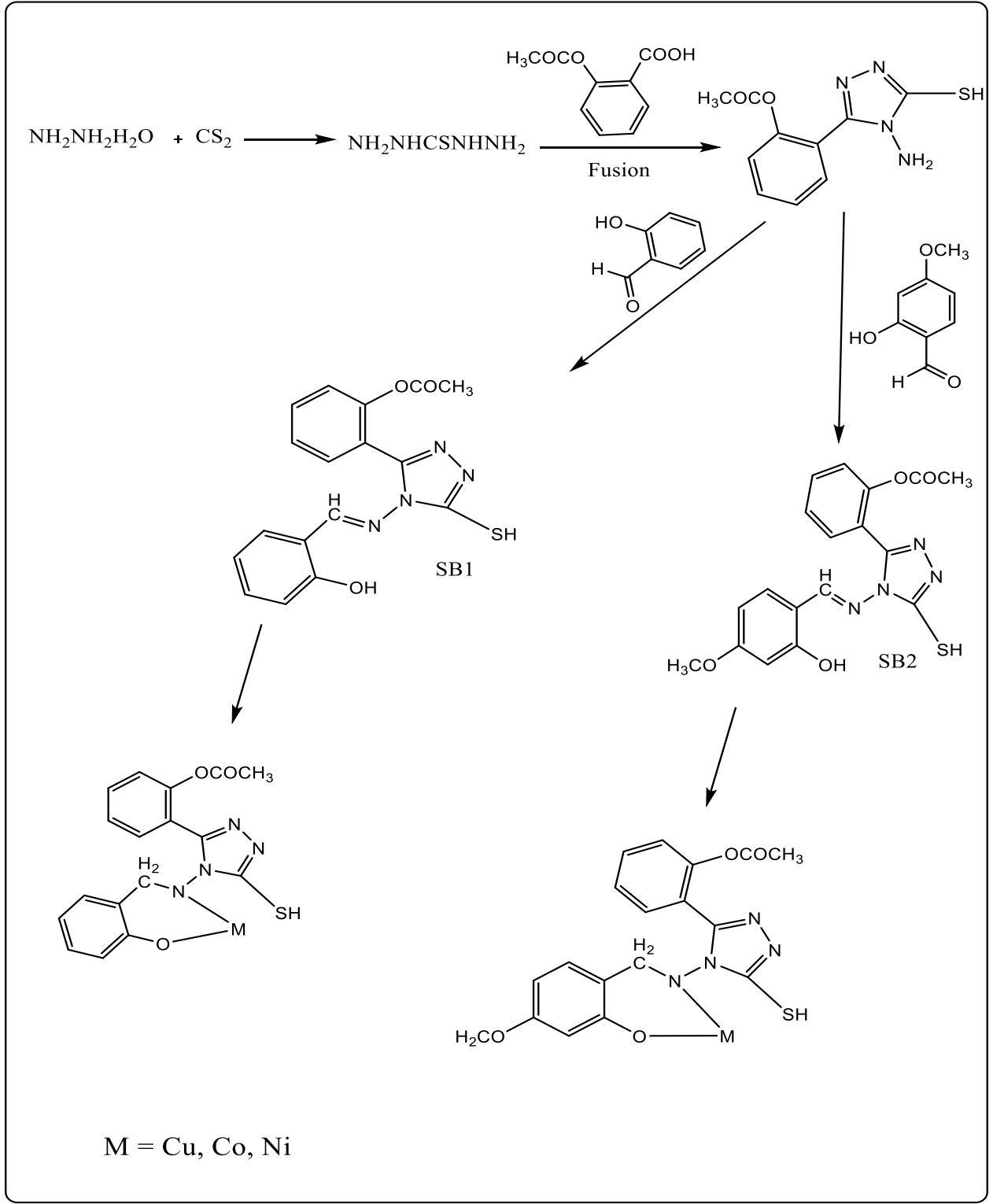

Scheme(1): Synthesis of compounds and complexes. 
The majority of the reactions between carbon disulfide and $\mathrm{N}$-nucleophiles involve addition of carbon disulfide to $\mathrm{N}-\mathrm{H}$ bonds. The products of these reactions, dithiocarbamate salts, can be transformed into dithiocarbamic acids and esters, which find application in the synthesis of a wide range of organosulfur compounds[19-21].

\section{Elemental Analysis}

The structure of the synthesized substituent chalcones and some heterocyclic compounds were confirmed by their elemental analysis. Found and calculated data, the calculated values of carbon, hydrogen, nitrogen and sulpher elements were situated within the range, which confirmed the validity of the suggested structure of the synthesized compounds.

Table 1. The elemental analysis of compounds.

\begin{tabular}{|c|c|c|c|c|c|c|}
\hline \multirow[t]{2}{*}{ Complex } & \multicolumn{3}{|c|}{ Found } & \multicolumn{3}{|c|}{ Calculated } \\
\hline & $\% \mathrm{C}$ & $\% \mathrm{H}$ & $\% \mathrm{~N}$ & $\% \mathrm{CC}$ & $\% \mathrm{H}$ & $\% \mathrm{~N}$ \\
\hline $\mathrm{Cu}\left(\mathrm{C}_{17} \mathrm{H}_{13} \mathrm{~N}_{4} \mathrm{O}_{3} \mathrm{~S}\right) \mathrm{Cl}_{2}$ & 41.68 & 2.60 & 11.30 & 41.86 & 2.69 & 11.49 \\
\hline $\mathrm{Co}\left(\mathrm{C}_{17} \mathrm{H}_{13} \mathrm{~N}_{4} \mathrm{O}_{3} \mathrm{~S}\right) \mathrm{Cl}_{2}$ & 42.21 & 2.68 & 11.49 & 42.26 & 2.71 & 11.59 \\
\hline $\mathrm{Ni}\left(\mathrm{C}_{17} \mathrm{H}_{13} \mathrm{~N}_{4} \mathrm{O}_{3} \mathrm{~S}\right) \mathrm{Cl}_{2}$ & 42.16 & 2.71 & 11.55 & 42.28 & 2.71 & 11.60 \\
\hline $\mathrm{Cu}\left(\mathrm{C}_{18} \mathrm{H}_{15} \mathrm{~N}_{4} \mathrm{O}_{4} \mathrm{~S}\right) \mathrm{Cl}_{2}$ & 41.70 & 2.88 & 10.78 & 41.75 & 2.92 & 10.82 \\
\hline $\mathrm{Co}\left(\mathrm{C}_{18} \mathrm{H}_{15} \mathrm{~N}_{4} \mathrm{O}_{4} \mathrm{~S}\right) \mathrm{Cl}_{2}$ & 42.00 & 2.90 & 10.88 & 42.12 & 2.95 & 10.92 \\
\hline
\end{tabular}

\section{F.TI.R. Spectral Study.}

The comparative analysis of the IRspectra of the complex and of the free ligand (Table 2)revealed that the absorption band characteristic of the stretching vibrations of $-\mathrm{C}=\mathrm{N}-$ (azomethane group) is shifted towards higher wave number from1612 $\mathrm{cm}^{-1}$ in the spectrum of the ligand to $1695 \mathrm{~cm}^{-1}$ in the complex [8,21]. This indicates the coordination of the nitrogen of this group with the metal [22]. A broadband appearing at $\sim 3566 \mathrm{~cm}^{-1}$ assigned to] $\mathrm{O}-\mathrm{H}$ in the Schiff base was no longer found in the spectra of the investigated metal complex [23] and, instead, appearance of a new band at $1272 \mathrm{~cm}-1 \mathrm{due}$ to] $(\mathrm{C}-\mathrm{O})$ stretching vibrations indicated deprotonation and coordination of the hydroxyl oxygen to the metal [24]. In addition, the appearance of new band at $335-\mathrm{cm}^{-1}$ showing the involvement of $\mathrm{M}-\mathrm{Cl}$ bond in complex formation, supporting the IR spectral study. Further conclusive evidence of coordination of the Schiff base with the metal ion was shown by the appearance of low frequency new band at $648 \mathrm{~cm}^{-1}$ due to metal-oxygen](M-O) vibrations [25, 26] and was observed in the spectra of the thus confirming participation of the oxygen atom in the coordination. Further coordination of metal to azomethane nitrogen is confirmed by a new band at $508 \mathrm{~cm}^{-1}$ with the involvement of the imidazole ring nitrogen in the coordination with metal ion [27] due to] $(\mathrm{M}-\mathrm{N})$.

Table 2. IR Spectral data of the synthesized compounds.

\begin{tabular}{|c|c|c|c|c|c|}
\hline $\begin{array}{l}\text { Sy.of } \\
\text { Comp. }\end{array}$ & $\begin{array}{c}v \mathrm{HC}=\mathrm{N} \\
\mathrm{cm}^{-1}\end{array}$ & $\begin{array}{l}\text { vC-O } \\
\mathrm{cm}^{-1}\end{array}$ & $\begin{array}{l}\mathrm{vC}=\mathrm{C} \\
\mathrm{cm}^{-1}\end{array}$ & $\begin{array}{c}v \mathrm{C}=\mathrm{O} \\
\mathrm{cm}^{-1}\end{array}$ & v Specific bands $\mathrm{cm}^{-1}$ \\
\hline $\mathrm{SB}_{1}$ & $1595 \mathrm{~cm}^{-1}$ & $\begin{array}{l}1296 \mathrm{~cm}^{-1} \\
1261 \mathrm{~cm}^{-1}\end{array}$ & $1485 \mathrm{~cm}^{-1}$ & $1665 \mathrm{~cm}^{-1}$ & $\begin{array}{c}3066 \mathrm{~cm}^{-1} 3107 \mathrm{~cm}^{-1} \\
\mathrm{C}=\mathrm{C}-\mathrm{H} \mathrm{Ar}\end{array}$ \\
\hline $\mathrm{SB}_{1} \mathrm{Ni}$ & $1610 \mathrm{~cm}^{-1}$ & $\begin{array}{l}1246 \mathrm{~cm}^{-1} \\
1296 \mathrm{~cm}^{-1}\end{array}$ & $1483 \mathrm{~cm}^{-1}$ & $1660 \mathrm{~cm}^{-1}$ & $\begin{array}{c}3234 \mathrm{~cm}-1 \mathrm{OH} \\
\mathrm{N}-\mathrm{Ni} 569, \mathrm{O}-\mathrm{Ni} 462\end{array}$ \\
\hline $\mathrm{SB}_{1} \mathrm{Co}$ & $1610 \mathrm{~cm}^{-1}$ & $\begin{array}{l}1246 \mathrm{~cm}^{-1} \\
1296 \mathrm{~cm}^{-1}\end{array}$ & $\begin{array}{l}1246 \\
1296\end{array}$ & $1658 \mathrm{~cm}^{-1}$ & $\begin{array}{l}\text { Co-O } 532 \\
\text { Co-N468 }\end{array}$ \\
\hline $\mathrm{SB}_{1} \mathrm{Cu}$ & $1604 \mathrm{~cm}^{-1}$ & $\begin{array}{l}1205 \mathrm{~cm}^{-1} \\
1246 \mathrm{~cm}^{-1} \\
\end{array}$ & $1444 \mathrm{~cm}^{-1}$ & $1666 \mathrm{~cm}^{-1}$ & $\begin{array}{l}\mathrm{Cu}-\mathrm{O} 569 \\
\mathrm{Cu}-\mathrm{N} 460 \\
\end{array}$ \\
\hline $\mathrm{SB}_{2}$ & $1610 \mathrm{~cm}^{-1}$ & $\begin{array}{l}1296 \mathrm{~cm}^{-1} \\
1247 \mathrm{~cm}^{-1}\end{array}$ & $1477 \mathrm{~cm}^{-1}$ & 1658 & $\begin{array}{c}3059 \mathrm{~cm}^{-1} 3008 \mathrm{~cm}^{-1} \\
\mathrm{C}=\mathrm{C}-\mathrm{H} \mathrm{Ar} \\
3240 \mathrm{OH}\end{array}$ \\
\hline $\mathrm{SB}_{2} \mathrm{Co}$ & $1606 \mathrm{~cm}^{-1}$ & $\begin{array}{l}1251 \mathrm{~cm}^{-1} \\
1294 \mathrm{~cm}^{-1}\end{array}$ & $1465 \mathrm{~cm}^{-1}$ & 1658 & $\begin{array}{c}3257 \mathrm{OH}, \mathrm{O}-\mathrm{Co} 578 \\
\text { N-Co } 466\end{array}$ \\
\hline $\mathrm{SB}_{2} \mathrm{Cu}$ & $1612 \mathrm{~cm}^{-1}$ & $\begin{array}{l}1247 \mathrm{~cm}^{-1} \\
1211 \mathrm{~cm}^{-1} \\
\end{array}$ & $1481 \mathrm{~cm}^{-1}$ & 1658 & $\begin{array}{c}3240 \text { OH O-Cu532 } \\
\text { N-Cu } 460 \\
\end{array}$ \\
\hline
\end{tabular}




\section{${ }^{1}$ HNMR Spectra.}

${ }^{1} \mathrm{HNMR}$ spectrum of the ligand $\left(\mathrm{SB}_{1}\right)$ shows a signal at $10.1 \mathrm{ppm}$ as singlet due to phenolic-OH [28]. And $10.2 \mathrm{ppm}$ for the complex $\mathrm{SB}_{2}$, the absence of any signal due to phenolic proton $(-\mathrm{OH})$ in this region indicates the involvement of phenolic oxygen in coordination via deprotonation [29], thus further supporting the IR spectral observations. In the ligand, the signal at $9.63 \mathrm{ppm}$ as singlet due to proton of azomethane group [30] shows an up field shifting of 1.18 ppm and appears at $10.81 \mathrm{ppm}$ in the complex indicating the coordination of azomethane nitrogen with metal [31]. The signals for the ligand were obtained at6.8-7.7 $\mathrm{ppm}$ [32] due to protons of aromatic rings $(8 \mathrm{H}, \mathrm{Ar}-\mathrm{H})$ which is shifted to higher field in the complexes due to shielding and appears as singlet and multiplet.

Table 3. ${ }^{1}$ HNMR Spectra data of synthetic compounds.

\begin{tabular}{|c|c|c|c|c|c|c|}
\hline \multirow[b]{2}{*}{ Comp. } & \multicolumn{6}{|c|}{ Chemical Shift $^{1} \mathrm{HNMR} \delta(\mathrm{ppm})$} \\
\hline & O-H & S-H & Ar-H & DMSO & N-H & Specific \\
\hline $\mathrm{SB}_{1}$ & 10.1 & 13.6 & $6.8-7.7$ & 2.5 & - & $\mathrm{CH}_{3} 2.0$ \\
\hline $\mathrm{SB}_{2}$ & 10.2 & 13.6 & $6.8-7.7$ & 2.5 & - & $\begin{array}{c}{\mathrm{O}-\mathrm{CH}_{3}}_{3} 3.8 \\
\mathrm{CH}_{3} 2.3\end{array}$ \\
\hline
\end{tabular}

Table $4 .{ }^{13} \mathrm{C}$ NMR Spectra data of synthetic compounds.

\begin{tabular}{|c|c|c|c|c|c|c|}
\hline \multirow[b]{2}{*}{ Comp. } & \multicolumn{6}{|c|}{ Chemical Shift ${ }^{13}$ CNMR $\delta(p p m)$} \\
\hline & $\mathrm{C}=\mathrm{O}$ & C-S-H & Ar-C & DMSO & $\mathbf{N}=\mathbf{C}$ & Specific \\
\hline $\mathrm{SB}_{1}$ & 161 & 172 & $116.6-160.4$ & 39.52 & 148 & $161 \mathrm{C}-\mathrm{OH}$ \\
\hline $\mathrm{SB}_{2}$ & 172 & 192 & $112.9-160$ & 39.52 & 148 & $\begin{array}{c}\mathrm{O}-\mathrm{CH}_{3} 56.07 \\
\mathrm{C}-\mathrm{CH}_{3} 10.8\end{array}$ \\
\hline
\end{tabular}

\section{Mass Spectra.}

The mass spectrum of A,B,C,D and E shows a molecular ion peak at m/z487 and 517 due to $[\mathrm{Cu}(\mathrm{L})]+; 476$ and 513 due to $[\mathrm{Co}(\mathrm{L})]+; 515$ due to $[\mathrm{Ni}(\mathrm{L})]_{+} \cdot$ which suggests the monomeric nature of the complex. The intense peak at $\mathrm{m} / \mathrm{z}$ 410.1 corresponds to loss of ligand molecule $\mathrm{A}+\cdot$, that is, $\mathrm{Cu}\left(\mathrm{C}_{11} \mathrm{H}_{10} \mathrm{Cl}_{2} \mathrm{CuN}_{4} \mathrm{O}_{2} \mathrm{~S}\right)+{ }^{\cdot}$ from indicating molecular mass of the ligand. Other peaks of appreciable intensity observed atm/z values of 241 due to loss of $(\mathrm{Cl})+\cdot$ and other peaks appears in 223, 92, and 41 due to losing $\mathrm{Cl} . \mathrm{C}_{6} \mathrm{H}_{7} \mathrm{~N}$ and $\mathrm{C}_{4} \mathrm{H}_{4}$. The intense peak at $\mathrm{m} / \mathrm{z} 517$ corresponds to loss of ligand molecule $\mathrm{B}+\cdot$, that is, $\left(\mathrm{Cu}\left(\mathrm{C}_{18} \mathrm{H}_{15} \mathrm{~N}_{4} \mathrm{O}_{4} \mathrm{~S}\right) \mathrm{Cl}_{2}\right)+\cdot$ from indicating molecular mass of the ligand. Other peaks of appreciable intensity observed atm/z values of 368, 120, 92 and 41.The intense peak at $\mathrm{m} / \mathrm{z} 410.1$ corresponds to loss of ligand molecule $\mathrm{C}+\cdot$, that is, $\mathrm{Co}\left(\mathrm{C}_{17} \mathrm{H}_{13} \mathrm{~N}_{4} \mathrm{O}_{3} \mathrm{~S}\right) \mathrm{Cl}_{2} \cdot$ from indicating molecular mass of the ligand. Other peaks of appreciable intensity observed $\mathrm{atm} / \mathrm{z}$ values of 368 due to loss of $(\mathrm{Cl})+\cdot$ and other peaks appears in 115,92 , and 69. The intense peak at $\mathrm{m} / \mathrm{z}$ 410.1 corresponds to loss of ligand molecule $\mathrm{D}+\cdot \cdot$, that is, $\mathrm{Co}\left(\mathrm{C}_{18} \mathrm{H}_{15} \mathrm{~N}_{4} \mathrm{O}_{4} \mathrm{~S}\right) \mathrm{Cl}_{2} \cdot$ from indicating molecular mass of the ligand. Other peaks of appreciable intensity observed atm/z values of 341 due to loss of $(\mathrm{Cl})+\cdot$ and other peaks appears in 120,92 , and 41 .The intense peak at $\mathrm{m} / \mathrm{z} 410$.1 corresponds to loss of ligand molecule $\mathrm{E}+\cdot$, that is, $\mathrm{Ni}\left(\mathrm{C}_{17} \mathrm{H}_{13} \mathrm{~N}_{4} \mathrm{O}_{3} \mathrm{~S}\right) \mathrm{Cl}_{2}$. from indicating molecular mass of the ligand. Other peaks of appreciable intensity observed atm/z values of 298 due to loss of $(\mathrm{Cl})+\cdot$ and other peaks appears in 120,92 , and 41 The relative intensities of these peaks give an assessment of the stabilities of the various fragments. Such type of fragmentation patterns has been reported by many workers [33-35 ].

\section{Conductance, Magnetic Susceptibility Measurements and Biological activity.}

The values the molar conductance of metal complexes were calculated at room temperature taking DMSO as a solvent and the results were shown in Table(6). The complexes were found to be an ionic in nature by conductivity measurements and have been found to posses 1:2(M:2L) stoichiometry. The molar conductance value are commonly used to estimated the electrolytic or non-electrolytic nature of the metal complexes. .The magnetic moment values of 1.540-1.7295.B.M. for $\mathrm{Cu}$ (II) complexes without doubt recommend octahedral geometry with one unpaired electron for $\mathrm{Cu}$ (II) complexes. The magnetic moment values of 3.863-4.039 B.M. for $\mathrm{Co}$ (II) complexes that recommend high spin octahedral geometry with three unpaired electron for $\mathrm{Co}$ (II) complexes. The magnetic moment value of 2.351B.M. for Ni(II) complex was matches to two unpaired electrons and octahedral geometry[36-39].

The metal complexes show higher anti bacterial and antifungal activity in comparison to free ligands. Also, metal complexes show higher antifungal activity against the Aspergillums species. The complexes show a significant increase in $\%$ inhibition zone for $\mathrm{SB}_{1} \mathrm{Cu}(15)$ to $\mathrm{SB}_{1} \mathrm{Co}(22)$. Similarly, the complexes $\mathrm{SB}_{1} \mathrm{Ni}, \mathrm{SB}_{2} \mathrm{Cu}$ and $\mathrm{SB}_{2} \mathrm{Co}$ shows a significant increase in percent of inhibition zone. Co(II) complexes show best anti bacterial and antifungal activity, followed by $\mathrm{Ni}$ (II) complexes . $\mathrm{SB}_{1} \mathrm{Cu}$ (II) complexes show the least activity as shown in Table (6). This inhibition behavior against bacteria and fungi might be due to azomethine (-HC=N-) linkage and metals atom present in these compounds. 
Table 5. magnetic susceptibility measurements and Conductance data of synthetic compounds.

\begin{tabular}{|c|c|c|c|c|c|c|c|}
\hline Com. & $\begin{array}{l}\text { Correc. } \\
\text { Factor } \\
\mathbf{D} \times 10^{-4}\end{array}$ & $\begin{array}{c}\text { Mass } \\
\text { magnetic } \\
\text { Suscepti } \\
\mathrm{Xg} \times 10^{-4}\end{array}$ & $\begin{array}{c}\text { Molar } \\
\text { magnetic } \\
\text { Suscepti } \\
\mathbf{X}_{\mathbf{m}}\end{array}$ & $\begin{array}{c}\text { Atomic } \\
\text { magnetic } \\
\text { Suscepti } \mathbf{X}_{\mathbf{A}}\end{array}$ & $\begin{array}{c}\text { Effective } \\
\text { magnetic } \\
\text { moment } \\
\mu_{\text {eff(B.M) }}\end{array}$ & $\begin{array}{c}\text { M.Wt } \\
(\mathrm{gm} / \mathrm{mol})\end{array}$ & $\begin{array}{c}\text { Molar } \\
\text { Conductivity } \\
\text { Ohm }^{-1}\end{array}$ \\
\hline $\mathrm{SB}_{1} \mathrm{Cu}$ & -3.793 & 0.013 & $6.34 \times 10^{-4}$ & $1.013 \times 10^{-3}$ & 1.540 & 487.82 & 35.6 \\
\hline $\mathrm{SB}_{2} \mathrm{Cu}$ & -3.957 & 0.017 & $\begin{array}{c}8.8 \times 1 \\
0^{-4}\end{array}$ & $1.276 \times 10^{-3}$ & 1.729 & 517.85 & 50.6 \\
\hline $\mathrm{SB}_{1} \mathrm{Co}$ & -3.793 & 0.124 & $5.991 \times 10^{-3}$ & $6.370 \times 10^{-3}$ & 3.863 & 483.21 & 44.6 \\
\hline $\mathrm{SB}_{2} \mathrm{Co}$ & -3.957 & 0.128 & $6.569 \times 10^{-3}$ & $6.965 \times 10^{-3}$ & 4.039 & 513.24 & 62.6 \\
\hline $\mathrm{SB}_{1} \mathrm{Ni}$ & -3.794 & 0.041 & $1.980 \times 10^{-3}$ & $2.359 \times 10^{-3}$ & 2.351 & 482.97 & 36.5 \\
\hline
\end{tabular}

Table 6.Antibacterial and antifungal activite

\begin{tabular}{|r|r|c|c|r|r|}
\hline \multirow{2}{*}{ No. } & \multirow{2}{*}{.Com } & \multicolumn{4}{|c|}{ Inhibition zone } \\
\cline { 3 - 6 } & & S.arureus & E.coli & Condida. & Asperillus \\
\hline 1 & $\mathrm{SB}_{1} \mathrm{Cu}$ & 15 & 11 & 18 & 30 \\
\hline 2 & $\mathrm{SB}_{1} \mathrm{Co}$ & 22 & 18 & 18 & 15 \\
\hline 3 & $\mathrm{SB}_{1} \mathrm{Ni}$ & 20 & 18 & 20 & 25 \\
\hline 4 & $\mathrm{SB}_{2} \mathrm{Cu}$ & 22 & 15 & 15 & 15 \\
\hline 5 & $\mathrm{SB}_{2} \mathrm{Co}$ & 22 & 18 & 20 & 25 \\
\hline
\end{tabular}

\section{CONCLUSION}

The study of the reaction between the transition metal and the derived Schiff base indicates its high stability. This encourages the synthesis and careful investigation of the nature of bonding between the Schiff base and the transition metal cation of important biological role, using physicochemical method of analyses. It is clear from above discussion that the fragmentation pattern and spectral studies of the complex confirm and illustrate the proposed geometry obtained by elemental analysis, IR, ${ }^{1} \mathrm{HNMR}$, and mass spectra.

\section{REFERENCES}

[1] Y. Shibuya, K. Nabari, M. Kondo et al., "The copper(II) complex with two didentateschiff base ligands.The unique rearrangment that proceeds under alcohol vapor in the solid state to construct noninclusion structure," Chemistry Letters, vol. 37, no. 1, pp. 78- 79, 2008.

[2] B. J. Gangani and P. H. Parsania, "Microwave-irradiated and classical syntheses of symmetric double Schiff bases of $1,1 \square$-bis(4-aminophenyl)cyclohexane and their physicochemical characterization," Spectroscopy Letters, vol. 40, no. 1, pp. 97-112, 2007.

[3] B. S. Kumari, G. Rijulal, and K. Mohanan, "Microwave assisted synthesis, spectroscopic, thermal and biological studies of some lanthanide(III) chloride complexes with a heterocyclic schiff base," Synthesis and Reactivity in Inorganic, MetalOrganic and Nano-Metal Chemistry, vol. 39, no. 1, pp. 24-30, 2009.

[4] M. Thankamony and K. Mohanan, "Synthesis, spectral studies, thermal decomposition kinetics, reactivity and antibacterial activity of some lanthanide(III) nitrate complexes of 2- (N-indole-2-one)amino-3-carboxyethyl-4,5,6,7tetrahydrobenzo[b]thiophene," Indian Journal of Chemistry A, vol. 46, no. 2, pp. 247-251, 2007.

[5] N. Raman, J. D. Raja, and A. Sakthivel, "Synthesis, spectral characterization of Schiff base transition metal complexes: DNA cleavage and antimicrobial activity studies," Journal of Chemical Sciences, vol. 119, no. 4, pp. 303-310, 2007.

[6] B. Halli and V. B. Patil, "Synthesis, spectral characterization and DNA cleavage studies of $\mathrm{Co}(\mathrm{II}), \mathrm{Ni}(\mathrm{II}), \mathrm{Cu}(\mathrm{II})$, $\mathrm{Zn}(\mathrm{II}), \mathrm{Cd}(\mathrm{II})$ and $\mathrm{Hg}(\mathrm{II})$ complexes with benzofuran-2-carbohydrazide schiff bases," Indian Journal of Chemistry A, vol. 50, no. 5, pp. 664-669, 2011.

[7] K. Shivakumar and M. B. Halli, "Synthesis, characterization and antimicrobial studies on metal complexes with a naphthofuran thiosemicarbazide derivatives," Journal of Coordination Chemistry, vol. 59, no. 16, pp. 1847-1856, 2006. 
[8] N. Bharti, S. Sharma, F. Naqvi, and A. Azam, "New palladium(II) complexes of 5-nitrothiophene-2-carboxaldehyde thiosemicarbazones: synthesis, spectral studies and in vitro anti-amoebic activity," Bioorganic \& Medicinal Chemistry, vol. 11, no. 13, pp. 2923-2929, 2003.

[9] A. A. Soliman, "Synthesis and properties of new substituted 1,2,4-triazoles: potential antitumor agents," Journal of Thermal Analytic Calculation, no. 63, p. 221, 2001.

[10] A. F. Petrovic, D. M. Petrovic, V. M. Leovac, and M. Budimir, "Ruthenium(II) complexes containing bidentate Schiff bases and their antifungal activity," Journal of Thermal Analytic Calculation, vol. 58, p. 589, 1999.

[11] Ivanovic, K. Andjelkovic, V. M. Leovac, L. J. Klisarov, M. Lazavevic, and D. Minic, "Molecular design of mononuclearcomplexes of acyclic Schiff-base ligands, Journal of Coordination Chemistry," Journal of Thermal Analytic Calculation, vol. 46, p. 1741, 1996.

[12] Z. M. Zaki, S. S. Haggag, and A. A. Soayed, "Synthesis, spectral characterization and DNA cleavage studies of $\mathrm{Co}(\mathrm{II}), \mathrm{Ni}(\mathrm{II}), \mathrm{Cu}(\mathrm{II}), \mathrm{Zn}(\mathrm{II}), \mathrm{Cd}(\mathrm{II})$ and $\mathrm{Hg}(\mathrm{II})$ complexes with benzofuran2- carbohydrazideschiff bases," Spectroscopy Letters, vol. 31, p. 757, 1998.

[13] S. O. Podunavac-Kuzmanovic, D. M. Cvetkovicand, and L. S. Vojinnovic, "Synthesis, characterization and molecular structure of a new tetramericpalladium ( II) complex containing Schiff bases derived from AMTTO (AMTT = 4-amino-6methyl-1,2,4-triazine-thione-5-one)," Original Scientific Paper, APTEFF, vol. 35, pp. 1-280, 2004.

[14] A. Mobinikhaledi, N. Forughifar, and M. Kalhor, "Synthesis, characterization, DNA binding and nuclease activity of binuclear copper( II) complexes of cuminaldehydethiosemicarbazones," Turkish Journal of Chemistry, vol. 34, pp. 367373, 2010.

[15] S. O. Podunavc-Kuzmanovic, L. Vojinovic, and D. M. Cvetkovic, "Synthesis, structure and biological activity of a new and efficient Cd(II)-uracil derivative complex system for cleavage of DNA,” ISIRR, vol. 64, pp. 40-44, 2003

[16] I. Vogel, Quantitative Inorganic Analysis, Longman Green andCo, London, UK, 1959.

[17] C. Perez, M. Paul, and p. Bazerque, "An antibiotic assay bythe agar well diffusion method," Acta BiologiaeetMedicinaeExperimentalis, vol. 15, pp. 113-115, 1990.

[18] Zaki N. Kadhim, Synthesis and Electrochemical Study of Cu(II) Complex with Neutral[N2O2] Donor Schiff Base, J. Mater. Environ. Sci. 6 (3) (2015) 693-698.

[19] K. Singh, Y. Kumar, P. Puri, C. Sharma, and K. R. Aneja,"Synthesis, spectroscopic, thermal and antimicrobial studiesof $\mathrm{Co}(\mathrm{II}), \mathrm{Ni}(\mathrm{II}), \mathrm{Cu}(\mathrm{II})$ and $\mathrm{Zn}(\mathrm{II})$ complexes with Schiffbase derived from 4-amino-3-mercapto-6-methyl-5-oxo1,2,4-triazine,” Medicinal Chemistry Research, vol. 21, no. 8, pp. 1708-1716, 2012.

[20] W. J. Geary, "The use of conductivity measurements in organicsolvents for the characterisation of coordination compounds,"Coordination Chemistry Reviews, vol. 7, no. 1, pp. 81-122, 1971.

[21] P. Murali Krishna, K. Hussain Reddy, J. P. Pandey, and S.Dayananda, "Synthesis, characterization, DNA binding andnuclease activity of binuclear copper(II) complexes of cuminaldehydethiosemicarbazones," Transition Metal Chemistry,vol. 33, no. 5, pp. 661-668, 2008.

[22] K. Shanker, R. Rohini, K. Shravankumar, P. M. Reddy, Y.-P.Ho, and V. Ravinder, "Synthesis of tetraaza macrocyclic PdIIcomplexes; antibacterial and catalytic studies," Journal of theIndian Chemical Society, vol. 86, no. 2, pp. 153-161, 2009.

[23] M. L. Hari Kumaran Nair and L. Shamla, "Synthesis, spectraland thermal studies of copper(II) complexes of azodyes derivedfrom 2,3-dimethyl-1-phenyl-4-amino-5-pyrazolone," Journal ofthe Indian Chemical Society, vol. 86, no. 2, pp. 133-138, 2009.

[24] G. O. Spessard, G. L. Miessler, Organometallic Chemistry (2nd ed.). New York: Oxford University Press. pp. 7982,2010 .

[25] A. L.Sargent, M. B.Hall, "Linear Semibridging Carbonyls. 2. Heterobimetallic Complexes Containing a Coordinatively Unsaturated Late Transition Metal Center". Journal of the American Chemical Society. 111 (5): 15631569,(1989).

[26] Li, P. Curtis, M. D. "A New Coordination Mode for Carbon Monoxide. Synthesis and Structure of $\mathrm{Cp}_{4} \mathrm{Mo}_{2} \mathrm{Ni}_{2} \mathrm{~S}_{2}\left(\eta{ }^{1}\right.$, $\mu_{4}$-CO)". Journal of the American Chemical Society. 111(21): 8279-8280, (1989)

[27] A. F. Holleman, E.Wiberg, N. Wiberg, Lehrbuch der AnorganischenChemie (102nd ed.). Berlin: de Gruyter. pp. 1780-1822,(2007) 
[28] J. R. Abraham and M. MobliAn NMR, IR and theoretical investigation of 1H Chemical Shifts and hydrogen bonding in phenols, ,45(10),865-877, 2007

[29] 1DilekŞenoland İsmet Kaya, Synthesis and characterization of azomethine polymers containing ether and ester groups, Journal of Saudi Chemical SocietyVolume 21, Issue 5, July 2017, Pages 505-516.

[30] S. H. Sumrra, M. Ibrahim, S.Ambreen, M.Imran, M. Danish, and F. S. Rehman,Synthesis, Spectral Characterization, and Biological Evaluation of Transition Metal Complexes of Bidentate N, O Donor Schiff Bases, Bio inorganic and applications, 1-10,(2014).

[31] C.P. Cheng, Y. S. Hwang and R.S. HwangProton NMR Studies of the Electronic Effect of Substituents at the Azomethine Carbon of N,N'.Bisethylene (Salicylideniminato) Cobalt (II) Complex, J. of Chinese chemical Society,67(6),457-462, (2020).

[32] Z. Prasil and W. Forst Mass spectrometry of azomethane, J. of Amer. Chem. Soc.,3344,(1968).

[33] E.Yousif, A.Majeeda K.Al-Sammarrae, N.Salih, J.Salimon, B.Abdullahc, Metal complexes of Schiff base: Preparation, characterization and antibacterial activity, Arabian Journal of Chemistry

[34] K. R. Joshi, ${ }^{1}$ A. J. Rojivadiya, ${ }^{1}$ and J. H. PandyaSynthesis and Spectroscopic and Antimicrobial Studies of Schiff Base Metal Complexes Derived from 2-Hydroxy-3-methoxy-5-nitrobenzaldehyde.

[35] G. G. MOHAMED, M.M. OMAR and A.M. HINDY,Metal Complexes of Schiff Bases: Preparation, Characterization, and Biological Activity,Turk J. Chem, 30, 361 - 382, (2006).

[36] S.Sandra, C. Blaga, C. Zivojin and V. Vesna, J.Seb .Chem.Sco.,68,641(2003).

[37] F. Cotton and G. Wilkinson, Advanced Inorganic Chemistry,4th ed.Wiley,Newyork (2010)

[38] O. Piovesane and C. Furlani, J. Inorg. Nucl. Chem., 30, 1249, (1968). 